\title{
GRID-CONNECTED PHOTOVOLTAIC SYSTEM DESIGN FOR LOCAL GOVERNMENT OFFICES IN NIGERIA
}

\author{
D. 0. Johnson ${ }^{1, *}$ and A. A. Ogunseye ${ }^{2}$

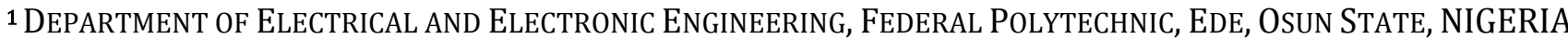

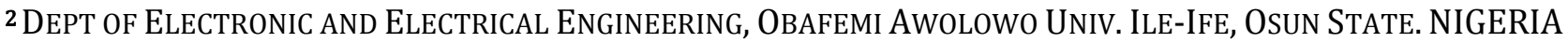 \\ E-mail addresses: ${ }^{1}$ pleasantdaniel@yahoo.com, ${ }^{2}$ abbey_ogunseye@yahoo.com
}

\begin{abstract}
Photovoltaic is direct conversion of sunlight into electricity through electronic means that occurs at atomic level of semiconductors materials. It is neat, silent and elegant process of generating electric power in environmentally friendly manner. In this paper, the design analyses roof-mounted Grid-connected 148.5kWp Photovoltaic System with Energy Storage for use in a Local Government secretariat in Nigeria. The design was simulated using PV*SOL software to evaluate the system's production performance and to know the amount of electric power generation for every day of the year. The result shows that the PV system's daily production far exceeds energy demand in the building. The maximum monthly demand is $2893.22 \mathrm{kWh}$ while the least energy production is $13,802 \mathrm{kWh}$ which occur in July. The highest production occurs in November with 20,258kWh; followed by March energy yield of 20,053kWh. Hence, the system could serve as good revenue source for the government by exporting more than $75 \%$ of the power generated to the grid in exchange for good cash from electricity utility; while at same time serving as motivation for home owners in the community as well as other governmental offices to generate some or all of their energy need.
\end{abstract}

Keywords: Photovoltaic, Photovoltaic design, Photovoltaic system, PV energy yield, Solar photovoltaic

\section{INTRODUCTION}

The place of constant supply of electricity in socioeconomy wellbeing of any nation is fundamentally important. In any modern society, electricity is a basic need, without which living condition becomes very substandard and smooth business operations become difficult. World over, the provision of electricity in any country has always been the responsibility of government. Of course, individuals particularly investors do contribute but the enabling environment and regulations are usually provided by the government.

With abundant fossil fuel resources Nigeria could not still use it to provide enough electrical energy even within cities where the national grid covers; not to even mention extending the grid to rural areas. As the trend of power generation going toward renewable (particularly solar) mainly because of environmental factors associated with fossil fuel use, as well as depletion of the fuel reserve. This offers good advantage for Nigeria government to provide incentives and education for its citizen on mass deployment of solar photovoltaic for electric power generation.

Solar energy resources is richly available in the country. Solar energy available on the roof of any residential building in the country can efficiently provide much or all of electric power needed by its occupants. Most countries that are doing very well in photovoltaic science and technology have less solar resource than Nigeria. Examples are Germany, Spain, Italy, Britain, France, and Japan.

The total amount of power generation as at August 2016 is still less than $5000 \mathrm{MW}$. Needless to say, this is grossly inadequate for population of over 180 million [1]. This can only supply a very small fraction of the population at a time.

Ideally, there should be $1000 \mathrm{MW}$ for every 1 million population, with this Nigeria need 180GW for its present population. So it is not feasible for government to increase generation from $5 \mathrm{GW}$ to $180 \mathrm{GW}$ in the next twenty years! This is just to say the least and be highly optimistic. However, photovoltaic deployment could prove transformational because it can be own by common individual which offers energy independence for vast majority with limited or no supply from the grid [2].

Most households in the country rely on petrol generator for electricity due to consistent power failure. Apart from fossil-fuel generator's disadvantages of environmental

\footnotetext{
* Corresponding author, tel: +234-803- $738-2203$
} 
pollution, greenhouse gas emission; it is much more costly in long term than photovoltaic generator $[3,4]$. The major limitation of photovoltaic system is its high initial cost. Then, the issue of variability and intermittency of the system. For instance, the output from PV generator at night is zero. However if energy storage device e.g. battery is incorporated, the PV generator charges the battery during the day, then at night the battery serves as the power source. Thus effectively mitigating PV intermittency and therefore enhancing reliability.

Photovoltaic System is a fast growing technology for electric power generation presently in the globe with average of over $35 \mathrm{GW}$ addition per year $[5,6]$. Photovoltaic offer many advantages as a means of power generation. Photovoltaic system has no moving part so the operation is completely noiseless and it is easy to install. PV power station is environmental friendly, no pollutant on air, land and water, no cost of working fluid or fuel.

Photovoltaic has good public acceptance, so it can be sited in a residential areas usually on roof top of domestic, commercial buildings and can also be mounted on ground. It can be owned by common individual unlike wind power and has durability of more than twenty five years with a very minimal maintenance and does not required highly skill person for its maintenance [7]. The cost of PV system is continuously falling $[5,6]$. Renewable energy like sunlight is freely available from nature at no cost

\section{PREVIOUS WORK}

Many research work has been done on renewable energy potential and resources availability in Nigeria. Quite a number centres on solar energy while some focus on solar photovoltaic and offer techno-economic analysis; very few engage in photovoltaic systems design. None seems to take solar photovoltaic to government door step by designing one for major government office. This is the gap this paper intend to fill. It is the authors' opinions that for massive deployment of photovoltaic system for electric power generation, government at the three-level need to take the lead in many ways. One, by using the PV instead of diesel generator in their offices. Two, by providing policy support and incentive. Three by educating the masses on photovoltaic and efficient energy use. This will go a long way in solving grossinadequate of the grid and epileptic power supply in the country as well as reducing carbon emission.

It is worth mentioning, however, that there are some government bodies, particularly some universities departments that use photovoltaic systems for power generation. Also there are numbers of privately owned photovoltaic systems and many use of solar PV in Nigeria for street lighting, community water pumping, vaccine refrigeration for rural clinics and house electrification in rural areas; mostly financed and executed by different government agencies [8].

Shaabana and Petinrin [9] after elaborating on the renewable energy potential in Nigeria, strongly advocate the need to tap into renewable energy as a means of overcoming inadequate supply from the grid. The paper suggests and outline policy framework aimed at encouraging deployment of renewable energy and as well underscore the need to back up the policies with actions and appropriate implementation. Ohunakina et al. [8] details some solar energy development and application in Nigeria. The authors identify drivers and barriers to solar energy development and suggested measures to overcome them. While pointing out that there are no comprehensive database of solar energy projects due to lack of synergy among major energy players in the country, it tried to provide a list of around sixty solar energy projects in Nigeria.

Akinyele and Rayudu [12] work focus on Photovoltaic Distributed Generation for energy-poor household in Nigeria. The author used HOMER software for modelling and analysis of PV system and its financial cost for typical village household. Their findings show that small scale power generation for energy-poor communities is feasible but need the support of government, private sectors and non-governmental organizations. The authors maintained that for optimal performance of PV system for poor communities require proper design and engineered using suitable simulation tool.

Ghafoorn and Munir [13] designed and performed economic analysis of off-grid PV System for household electrification in Faisalabad city, Pakistan. The authors concluded that unit cost of off-grid PV electricity is lower than the unit cost charged from the grid supply to residential areas, thereby making the system economically and technically viable for residential electrification.

Adaramola [14] used HOMER energy optimisation software to examine the techno-economic viability of 80kWgrid-connected solar PV system in the city of Jos, northern part of Nigeria. The author's design is in such a way that when PV system supplies more energy than needed, the excess is exported to the grid. When the supply from the PV system is less than demand, power is taken from the grid. At the cost of $\$ 2400 / \mathrm{kW}$ with irradiation of $6 \mathrm{kWh} / \mathrm{m}^{2}$, the result gives the levelised cost of electricity to be $\$ 0.103$ at $331,536 \mathrm{kWh}$ energy yield per year from the PV system. The author concludes that the project is economically viable though the initial investment cost is very high and therefore requires favourable policy and government incentive for the project implementation.

Vol. 36, No. 2, April 2017 
A. H. Mondal and S. Islam [15] examined potential and viability of grid-connected solar PV system in Bangladesh, utilizing a proposed 1MW grid-connected solar PV system in fourteen different location in the country. In their study, the authors use GeoSpatial toolkit, NASA SSE solar radiation data and several simulation software like HOMER and RET Screen. The technical potential of grid-tied solar PV in the country was estimated to be $50.17 \mathrm{GW}$. They also found that energy yield from the different location varies between $1653 \mathrm{MWh}$ and $1854 \mathrm{MWh}$. The study concluded that all indicators favours deployment of the proposed PV system and that unit cost of the system is lower than the grid-connected fuel-oil based power generation.

D.O. Johnson [7] in Cardiff (UK) city, studied the energy yield on the same area at the same location of four PV module technologies of Heterojunction with Intrinsic Thin-layer (HIT) polycrystalline silicon (p-Si), cadmium telluride (CdTe) and copper indium selenide (CIS) using PVSOL* $^{*}$ software to compare their energy yield. The four modules were installed on a rooftop area of almost $2000 \mathrm{~m}^{2}$. The HIT yield far exceed other, next is $\mathrm{p}$-Si while CdTe and CIS energy production were almost the same. In a similar study the same year; Kumar, Sudhakar and Baredar in 2016 [16] evaluated the feasibility of $110 \mathrm{kWp}$ grid-connected photovoltaic system for residential hostel building in India. The authors use four PV modules technologies of amorphous silicon (a-Si), crystalline silicon (c-Si), (CdTe) and (CIS). The technical performance analysis was carried out with Solargis PV Planner software. Their findings shows that in that particular location, although the four technologies perform satisfactorily, a-Si performance is superior to other technologies, yielding an energy of $181.1 \mathrm{MWh}$ in a year.

R. Carbone in 2009 [17] experimented with small-scale prototype of grid connected PV system with energy storage in battery. He found out that energy storage by means of battery, operated in a distributed manner enhance energy yield of grid connected PV power plant by naturally catching the maximum power point (MPP)of the module, particularly in mismatching condition. Thus, offering a good alternatives to other technical solutions like power electronic converters connected in cascade to each modular PV generator.

Pietruszko and Gradzki [18] studied the performance of the first grid-connected small PV system in Poland. The study involve review of climate and solar radiation conditions at the site. System performance through the energy delivered to the grid was assessed, system efficiency, system reliability and system component were appraised. The authors' findings shows that the system performance exceeded computer simulation expectation. Therefore recommended the duplication of the projects.
Mitscher and Ruther [19] work on economic competitiveness of grid-connected, distributed solar photovoltaic generation using small scale roof top installations in five Brazilian state capitals. Using the metric of net present value (NPV) and levelized cost of electricity (LCOE) analyses. The result of their analysis shows that solar PV electricity with government tariff is already competitive in the country. The work demonstrate high potential of distributed generation with photovoltaic in Brazil and that under certain conditions, grid-connected PV can be economically competitive in a developing countries.

All these and many other recent studies seems to concur that solar photovoltaic is cost competitive with grid. The studies also established a high initial cost and hence recommend favourable policy, government support and incentive for mass deployment of PV system.

\section{METHODOLOGY}

Ife-Central Local Government secretariat is located in IleIfe, an ancient and major city on 7.480N, 4.560E in southwestern Nigeria. The secretariat is the seat of the city's administration. The building was surveyed to determine the best location for PV power plant and to estimate electrical load usage in the building. It was decided to be sited on the building's concrete rooftop. The roof is horizontally flat which offers advantage of flexibility in choosing the desired angle of tilt or option of variable tilt angle for maximum solar energy tracking.

The simulation is done with PV*SOL 2016 version. $\mathrm{PV}^{*} \mathrm{SOL}$ is simulation software specially design for solar photovoltaic power analysis. It is designed and developed in Germany, one of the world's leading countries in photovoltaic technology and deployment $[20,21]$. The software automatically supplies solar irradiance data of most cities in the world and has up to date database of all commercially available PV module device technologies and their electrical characteristics.

Out of numerous commercially available PV module technologies in the market today, the authors prefers to use Hetero junction with Intrinsic Thin-layer (HIT) module because; presently it is among the most efficient PV technologies. It offers advantage of higher energy yield per given space/area. In addition, HIT incorporate light capturing technology, reducing reflection and scattering of light; producing power from both side of the module. It also work well when there is cloudy weather and lower insolation and as well give high performance at high temperature. The characteristics of the module as given by the manufacturer is shown in Table 1 : 
Table 1: Specifications of HIT330 Module

\begin{tabular}{ll}
\hline Rated Power $\left(\mathrm{P}_{\max }\right)$ & $330 \mathrm{~W}$ \\
Maximu Power Voltage $\left(\mathrm{V}_{\mathrm{pm}}\right)$ & $58.0 \mathrm{~V}$ \\
Maximum Power Current $\left(\mathrm{l}_{\mathrm{pm}}\right)$ & $5.70 \mathrm{~A}$ \\
Open Circuit Voltage $\left(\mathrm{V}_{\mathrm{oc}}\right)$ & $69.7 \mathrm{~V}$ \\
Short Circuit Current $\left(\mathrm{l}_{\mathrm{sc}}\right)$ & $6.07 \mathrm{~A}$ \\
Temperature Coefficient $\left.\mathrm{P}_{\max }\right)$ & $-0.30 \% /{ }^{\circ} \mathrm{C}$ \\
Temperature Coefficient $\left(\mathrm{V}_{\mathrm{oc}}\right)$ & $-0.174 \mathrm{~V} /{ }^{\circ} \mathrm{C}$ \\
Temperature Coefficient $\left(\mathrm{l}_{\mathrm{sc}}\right)$ & $1.82 \mathrm{~mA}$ \\
NOCT & $42.2^{\circ} \mathrm{C}$ \\
CEC PTS Rating & $306.5 \mathrm{~W}$ \\
Cell Efficiency & $22.09 \%$ \\
Module Efficiency & $19.7 \%$ \\
Watts per Ft. & $18.3 \mathrm{~W}$ \\
Maximum System Voltage & $600 \mathrm{~V}$ \\
Series Fuse Rating & $15 \mathrm{~A}$ \\
Dimensions L $\times \mathrm{W} \times \mathrm{H}$ & $159 \times 1053 \times 35 \mathrm{~mm}$ \\
Module Area & $1.67 \mathrm{~m}^{2}$ \\
Weight & $18.5 \mathrm{~kg}$ \\
Operating Temperature & $-40{ }^{\circ} \mathrm{C}$ to $85^{\circ} \mathrm{C}$ \\
Warranted Tolerance $(-/+)$ & $+10 \% /-0 \%$ \\
\hline
\end{tabular}

\section{LOAD PROFILE OF THE BUILDING}

The energy consumption data (electricity bills) collected is not reliable as there are issues with most metering systems in Nigeria. So an attempt is made to calculate the actual energy demand of the building based on loads in the building. Table 2 below gives the electrical loads in the building, their quantity and capacity as well as estimated monthly total consumption. It should be noted that consumption is not constant every day and month. Demand normally increases during dry season in most Nigeria offices due to air condition being on most of the time for cooling. In the Table 2, miscellaneous loads account for other loads like phone charging, microwave heating, electric kettle for water heating etc. The idea is to obtain workable and reasonable estimate amount of electricity consumption in the building which should be very close to actual consumption. Figure 1 shows the IfeCentral Local Government secretariat building.

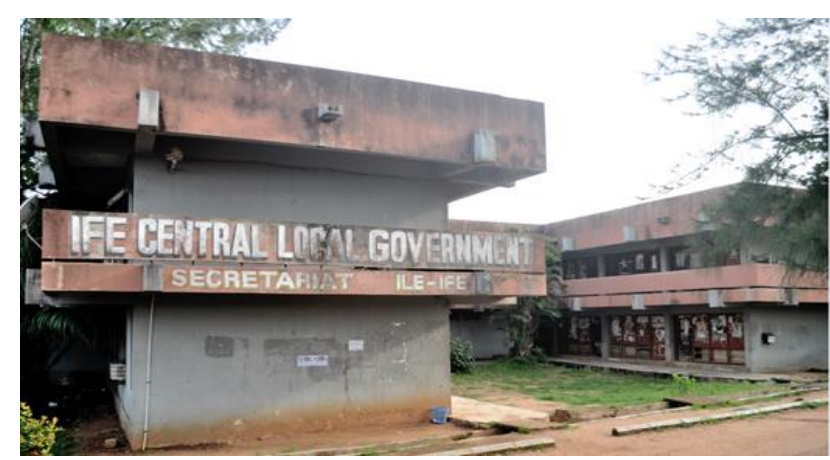

Figure 1: Ife-Central Local Government Secretariat

\section{SYSTEM DESIGN}

\subsection{Design Calculation of the PV Power Plant}

The peak demand of the building is $2,893.22 \mathrm{kWh}$ as estimated in Table 2. The intention is to generate enough power to first satisfy the energy need of the secretariat building and export excess to the distribution grid. The building roof area is spacious enough to accommodate this.

The building's horizontally-flat roof is not perfectly rectangular. So the area of each section is added together to give $1167 \mathrm{~m}^{2}$. Since the area of each module is $1.674 \mathrm{~m}^{2}$, then, the roof can accommodate $1167 \div 1.674=$ 697.13 modules.

All the roof space is usable but provision has to be made for free movement in-between the arrays for inspection and maintenance. When this is factored in, the space only accommodates 450 modules.

\subsection{Array Configuration}

Array is a series-parallel connection of PV modules. There are three arrays in this design; each consists of 150 HIT PV modules for each of the three-phase power system. Modules are first connected in series (string) to produce the required voltage. The strings are then combined in parallel to increase the current.

Table 2: Estimation of electric power demands in the building

\begin{tabular}{|c|c|c|c|c|c|}
\hline Loads & Quantity & $\begin{array}{l}\text { Wattage } \\
\text { (W) }\end{array}$ & $\begin{array}{l}\text { Usage duration } \\
\text { hours/day }\end{array}$ & $\begin{array}{l}\text { Daily consumption } \\
(\mathrm{kWh})\end{array}$ & $\begin{array}{l}22 \text { working days monthly } \\
\text { consumption }(\mathrm{kWh})\end{array}$ \\
\hline Lighting & 156 & 20 & 8 & 24.96 & 549.12 \\
\hline Fans & 36 & 60 & 5 & 10.80 & 237.60 \\
\hline Computer & 25 & 120 & 5 & 15.00 & 330.00 \\
\hline Printer & 7 & 120 & 2 & 1.68 & 36.96 \\
\hline Photocopier & 5 & 150 & 2 & 1.52 & 33.44 \\
\hline Air condition & 12 & 1000 & 4 & 48.00 & $1,056.00$ \\
\hline Television & 7 & 75 & 6 & 3.15 & 69.30 \\
\hline Refrigeration & 3 & 200 & 24 & 14.40 & 316.80 \\
\hline Miscellaneous & & & & 12.00 & 264.00 \\
\hline TOTAL & & $3000^{*}$ & & 131.51 & 2893.22 \\
\hline
\end{tabular}

$30000^{*}$ (the total wattage is summed up to be $22,995 \mathrm{~W}$ but $7005 \mathrm{~W}$ is added for future load increase) 
The required AC voltage will determine the DC voltage needed from a PV module string. In Nigeria power system, a single phase is around $240 \mathrm{~V} /$ phase, $415 \mathrm{~V} \mathrm{~L}-\mathrm{L}$ AC. So the equivalent $\mathrm{DC}$ phase voltage is given by:

$$
V_{d c}=\sqrt{2} V_{a c}=\sqrt{2} \times 240=339.41 \mathrm{~V}
$$

$10 \%$ is added to accounts for the ripples of the specified voltage in the design.

$$
V_{d c}=\sqrt{2} \times 240+10 \%=373.35 \mathrm{~V}
$$

The open circuit voltage $V_{\text {oc }}$ of the module is $69.7 \mathrm{~V}$. Therefore the number of modules in string.

$$
V_{d c} \div V_{o c}=\frac{373.35}{69.05}=5.41 \text { modules } \Rightarrow \text { 6modules }
$$

Thus string of six modules gives the maximum power point voltage at Standard Test Condition (STC) to be:

$$
6 \times V_{m p}=6 \times 58=348 \mathrm{~V} \text {. }
$$

The open circuit voltage of the string at STC equals

$$
6 \times V_{0 c}=6 \times 269.07=414.42 \mathrm{~V}
$$

This is up from $373.35 \mathrm{~V}$ of $\mathrm{V}_{\mathrm{dc}}$ actually required. The excess will take care of losses along the cable and voltage variation from the $\mathrm{PV}$ generator due to temperature increase above $25^{\circ} \mathrm{C}$ and other variations in environmental condition (irradiance).

In addition, the number of modules in string can only be a whole number, more so that we are using modules of similar electrical characteristics. Also, the output of the PV array will never be constant, although MPPT will cause it to operate at maximum power point irrespective of changing weather; yet provision still need to be made for voltage variation. This is design for worst-case scenario. Therefore, whatever voltage that is coming from PV array or the battery bank, the buck-boost DC-DC section regulate it to $375 \mathrm{~V}$ and feeds the inverter input. The inverter is capable of accepting voltage between 250 to $500 \mathrm{~V}$. Since the six modules are in series, the short circuit current remain the same at 6.07A.

Twenty-five of this string connection in parallel produces $414.42 \mathrm{~V}$ and $151.75 \mathrm{~A}$ or $348 \mathrm{~V}, 142.2 \mathrm{~A}$ at maximum power point. That is, the voltage remain the same while the current is multiply by 25

$$
\begin{aligned}
& 25 \times \mathrm{I}_{\mathrm{sc}}=25 \times 6.07=151.75 \mathrm{~A} \\
& 25 \times \mathrm{I}_{\mathrm{mp}}=25 \times 5.7=142.50 \mathrm{~A}
\end{aligned}
$$

The parallel connection of strings is to obtain higher current and subsequently achieve more power. So each phase of the DC side is $62.89 \mathrm{kVA}, 414.42 \mathrm{~V}, 151.75 \mathrm{~A}$. This is the input of the system inverter. These outputs feed three different $70 \mathrm{~kW}$ inverters. The inverters supply three-phase gear switch or AC bus which in turns supplies $415 \mathrm{~V}$ distribution line, a micro grid in the community.

Also various distribution boxes feeding different section of the building is supplied from the main switch gear. The meter reads the amount of power generated by the PV System as well as the amount supplied to the grid.
The arrays of modules are rooftop-installed due south on right-angle triangle shaped mounting structure of angle $15^{0}$ and $75^{\circ}$. The tilt angle of each array is $15^{\circ}$ to the horizontal instead of $7^{0}$, the latitude angle of the location.

\subsection{Shading}

Particular attention is given to shading and it is ensure there is no shading between the hour of 9am to $3: 30 \mathrm{pm}$ which are the prime sunny and office hours. The software was also use to investigate possible shadow by array itself by calculating percentage shading which gives $0.1 \%$ in the evening. This is insignificant and at a time much is not expected from the generator. Although, there are two small trees in the vicinity, this can be taken off during implementation.

\subsection{Components Rating}

In PV systems, the DC cables should be waterproof and be of high temperature rating at least $80^{\circ} \mathrm{C}$; and should be installed in such a way to reduce the risk of earth fault or short circuits. The cable should be of the size that will not allow more than $3 \%$ of voltage drop between the array and the inverter. In addition, all DC component rating (conductor, disconnector, switches etc.) should be at least $[22,23]$ :

$$
\begin{aligned}
& \text { Voltage: } \mathrm{V}_{\mathrm{oc}} \times 1.15=78.06 \mathrm{~V} \\
& \text { Current: } \mathrm{I}_{\mathrm{sc}} \times 1.25=7.59 \mathrm{~A}
\end{aligned}
$$

\subsection{Cable Sizing}

Wiring is very essential in PV system both for safety and effective performance of the PV system. It is necessary that conductors and insulation are rightly sized. If cables are under-sized, it could result in fire hazard and high losses across the cables. There are three major types of cable in PV system: array cable, string cable and AC cables.

For main DC cable with M numbers of parallel connection of stings with $\mathrm{N}$ modules, the rating should be $1.15 \times \mathrm{N} \times$ $\mathrm{V}_{\text {oc }}$ and $1.25 \times \mathrm{M} \times \mathrm{I}_{\text {sc }}[22,23]$ :

Main DC cable rating:

$$
\begin{array}{cl}
\text { Voltage: } & \mathrm{V}_{\mathrm{oc}} \times 6 \times 1.15=480.93 \mathrm{~V} \\
\text { Current: } & \mathrm{I}_{\mathrm{sc}} \times 25 \times 1.25=189.69 \mathrm{~A}
\end{array}
$$

\subsection{Battery}

The building is mostly occupies during the day since it is office complex. However, provision is made for energy storage to improve reliability of the system in case of cloudy weather and for security light of the building' surrounding at night when the output from the PV system is zero. In this design, the battery is meant to power important load like lighting and possibly some computer systems and fans. If air condition or more load are to be use during this period, then power has to be imported from the grid.

Vol. 36, No. 2, April 2017 
Deep cycle battery is mostly recommended type for PV systems because it is specifically designed to operate (discharge) to low energy level and can be recharged rapidly over and over again, day in day out for many years [24, 25].

The required battery capacity for PV design is given by: Battery Capacity $=\left\{\mathrm{L}_{\max } \times \mathrm{D}_{\text {aut }}\right\} \div\left\{\mathrm{V}_{\mathrm{nb}} \times \eta \times \mathrm{D}_{\mathrm{d}}\right\}$ Where:

$\mathrm{L}_{\max }$ is the total maximum load in the building, $\mathrm{D}_{\text {aut }}$ is the day of autonomy, i.e. the numbers of days the battery is expected to run before recharging, $V_{n b}$ is the nominal voltage of the battery, $\eta$ is the battery efficiency, $D_{d}$ is depth of discharge and it is usually taken to be 0.8 i.e. the battery discharge up to $80 \%$

In this design, the battery efficiency is taken to be $85 \%$, the total maximum load is $132 \mathrm{~kW}$ as calculated table 2 , day of autonomy to be 1 ; depth of discharge to be 0.8 (i.e. to continue discharging until it reduces to $20 \%$ full) ; system DC voltage to be $414.42 \mathrm{~V}$. The battery rating is 60V $120 \mathrm{Ah}$

Therefore the battery bank capacity

$$
\begin{gathered}
=\left\{132 \times 10^{3} \times 1\right\} \div\{360 \times 0.85 \times 0.8\} \\
=539.22 \mathrm{Ah}
\end{gathered}
$$

Battery in series $=$ system voltage/nominal battery voltage

$$
\begin{gathered}
=373.35 \div 60 \\
=6.22 \Rightarrow 6 \text { or } 7 \text { batteries }
\end{gathered}
$$

7 batteries in series will give $420 \mathrm{~V}$ which is higher than normal supply from the PV array, although DC-DC can step it down. It is advisable to use less or the same normally maximum PV production of $414 \mathrm{~V}$ open circuit at STC. This will allow for efficient charging of the battery by PV DC supply. In addition, higher PV voltage relative to battery voltage help MPPT charge controller to function more efficiently. Besides, the output from battery is usually constant over several hours unlike PV array. So 5 or 6 batteries in series will be most appropriate which gives 300 or $360 \mathrm{~V}$. It is then regulated to 373.35 by DC-DC converter which incorporate MPPT Charge controller features.

Battery in Parallel $=$ battery bank capacity $\div$ battery rating

$$
=539.22 \div 120=4.49 \Rightarrow 5
$$

Five is preferred so as to increase the battery capacity. In summary the battery bank consist of 30 batteries each rated $60 \mathrm{~V} 120 \mathrm{Ah}$ with total output of 360VDC 539.22Ah

\subsection{MPPT Charge Controller}

Charge controller monitors the charging of the battery to ensure it is not overcharged. Once the battery is fully charged, it cut off the DC supply to the battery. It also prevent over-discharge of the battery by disconnecting the load when the battery has discharge to pre-set level. This is to prolong the battery life. Overcharging and over discharging of battery shorten its service life quickly.
Hence, the need for battery operation monitoring by charge controller

Apart from functions of peak power tracking and battery charging; the MPPT charge controller employ in this design also performs as buck-boost switching regulator. It regulates the battery and PV modules output voltage to 373.35V and input it into inverter for onward conversion to AC power.

\subsection{Inverter}

Inverter is a device that converts $\mathrm{DC}$ from $\mathrm{PV}$ array to $\mathrm{AC}$ electricity. Photovoltaic modules produce DC electricity. Most load are design to operate on AC electrical power. Inverters are very important part of PV systems where alternating current output power is required. Transformer less grid-tied inverter was specifically designed for the system. Three 70kVA converter are to be used. The designed inverter consists of DC-DC section and DC to AC part.

The DC-DC section is to ensure constant DC input into DC-AC section because of variation of PV output due to changing environmental temperature, irradiance and the effect of maximum power point tracking [26]. The inverter is design to track the maximum power points of the PV so as to optimise power production and as well support ancillary services like reactive power control and frequency regulation. The converter has efficiency of 94.33\% Inverter should be installed in area with sufficient ventilation and should not be exposed to sunlight so that it can operate at its maximum efficiency. There are two ratings that determine the inverter capacity in PV power system [27].

$>$ Must be at least $25-30 \%$ of total wattage for standalone PV system and should be at least three times (300\%) of the total wattage of load like motor, air condition or any other load with high starting current is included.

$>$ Must never be less than PV capacity

On the first conditions, since inductive load are included, then three times the total wattage on each will be appropriate. So the inverter capacity should not be less than

$$
3 \times 30000 \mathrm{~W} / 3=30 \mathrm{~kW} .
$$

Note that $30000 \mathrm{~W}$ was total wattage on Table 2. The $30000 \mathrm{~W}$ is for three phase, a phase gives $30000 / 3$ for equal distribution of loads. On second condition, since each phase of the PV array is $62.99 \mathrm{kVA}$, then inverter capacity should be $\geq 63 \mathrm{~kW}$ assuming power factor of unity.

It should be noted that the first condition satisfies the load connected (stand-alone PV) condition while the second fulfil grid connected PV system. So to satisfy both conditions and as well factor in its efficiency (assume $90 \%$ ), inverter rating is selected to be $70 \mathrm{~kW}$. The inverter in this design is capable of accepting voltage 
between 250 to $500 \mathrm{~V}$; the buck-boost DC-DC section regulate it to $373 \mathrm{~V}$

\subsection{Circuit Diagram}

The circuit is as shown in Figure 2. The circuit consist of arrays of PV modules, DC disconnector, inverter, ac isolator (switch gear), AC bus, charge controller, metering device, power diode, over current and overvoltage protection devices. Table 3 shows the design specification of major component of the PV plant.

\subsection{Safety and Protection Measures}

\subsubsection{Over current and Overvoltage Protection}

If the parallel connection consists of three or more string as in this design, then string over current protection need to be provided to protects modules and conductors from excess current fault [28]. The fuse is installed in series with each string. The fuse may be fitted for both live and neutral PV cable [22]. This is to minimise safety hazard and also isolate faulty strings so that the rest of strings can continue to generate power. The rating of the protecting fuse should be [30-31].

Current rating $\geq 1.56 \times$ Isc and $\leq 2.0 \times \mathrm{I}_{\mathrm{sc}}$ $\geq 1.56 \times 6.07 \leq 2 \times 6.07 \geq 9.47$ but $\leq 12.14 \mathrm{~A}$

Voltage rating $\geq 1.2 \times \mathrm{M} \times \mathrm{V}_{\mathrm{oc}}=1.15 \times 6 \times 69.7=$ 480.93V

\subsubsection{Surge and Lightning Protection}

Direct lightning strike is more likely to induce surge and cause damage to PV system since the PV generator is installed outdoors in open space. A Surge protective device is therefore required on both polarity. In this design lightning arrestor may be installed to divert the surge to the earth. Effective grounding play a key role in protection from lightning surge.

\subsubsection{Isolating Devices}

Isolating devices are provided in the system at the DC side as DC disconnector to allow solar energy source to be disconnected if a fault occurs or when maintenance is required. Disconnector may also be at individual string to allow for each string disconnection. It should be noted, however that PV array cannot be switched off as long as they are exposed to sunlight. During daylight, the DC terminal of the array will be live and therefore extra care should be taken for anyone walking or working around it.At the AC side an isolator is installed to provide isolation of the $\mathrm{AC}$ side when servicing is requires.

\subsubsection{Grounding}

National Electricity Code (NEC) 690 standard requires the system and interface equipment should be grounded and monitored. Grounding or Earthing is connection of electrical system to the general mass of the earth. Grounding is very essential in PV system for safety of the system and users; as well protection against earth fault. In this design, exposed non-current-carrying metal parts of components and devices are to be effectively grounded. Earthing standard considered in this design are BS 7671, BS 7430 and BS 6651.

\subsubsection{Islanding}

This is a situation in which distributed generation, for instance, Grid connected PV power plant, continue to supply power to part of the grid when the section of the grid has been isolated from the main source. This means there is still power in the grid section when it is presumed or supposed to be dead. Islanding can be intentional or unintentional. Unintentional islanding is very hazardous to maintenance engineer who may want to work on the power line, thinking the line is safe with the assumption that the supply is off. However, deliberate islanding can be very beneficial in providing supply to mini-grid in area where utility supply is unreliable [32]. Grid-tied Inverter should have feature to recognise the condition of the grid and respond appropriately to prevent unintentional islanding to safeguard people and equipment involved.

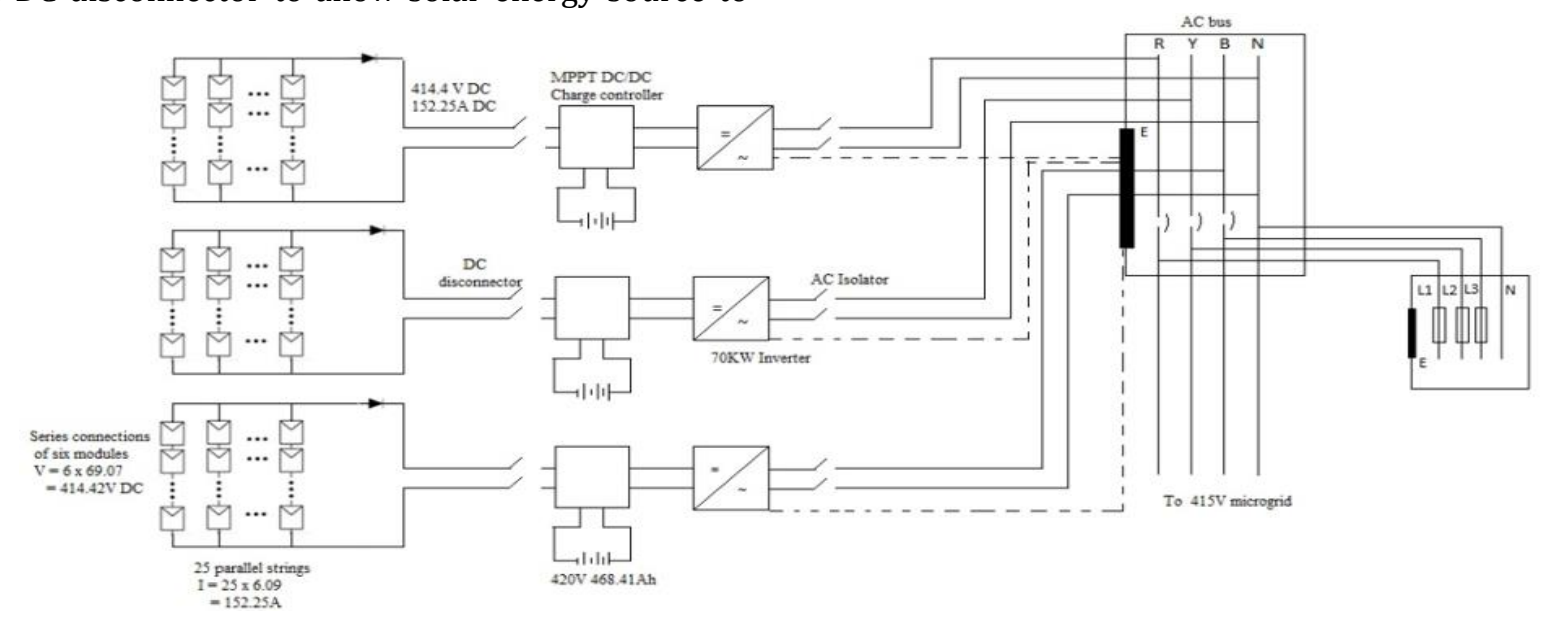

Figure 2: Schematic diagram of 148.5kWp PV power plant 
Table 3: System Specification

\begin{tabular}{|c|c|}
\hline \multicolumn{2}{|c|}{ PV Plant specification } \\
\hline Plant capacity & $148.5 \mathrm{~kW}_{\mathrm{p}}$ \\
\hline Average sun hour/day & 7.5 \\
\hline No of module & 450 \\
\hline No of phases & $3 \varphi$ \\
\hline DC voltage $V_{d c}$ & 414 \\
\hline Dc current $I_{d c}$ & $152 \mathrm{~A}$ \\
\hline \multicolumn{2}{|c|}{ Inverter specification } \\
\hline Quantity & Three, $1 / \varphi$ \\
\hline Capacity & 70kW(single $\varphi)$ \\
\hline $\mathrm{V}_{\mathrm{dc}}$ (input) & $373 \mathrm{~V}$ \\
\hline $\mathrm{V}_{\mathrm{ac}}$ (output) & 240/phase \\
\hline $\mathrm{I}_{\mathrm{dc}}$ (input) & $152 \mathrm{~A}$ \\
\hline Frequency & $50 \mathrm{~Hz}$ \\
\hline \multicolumn{2}{|c|}{ Battery Specification } \\
\hline Nominal voltage & $60 \mathrm{~V} \mathrm{DC}$ \\
\hline Rating & 120Ah \\
\hline Number in series & 6 \\
\hline Number in parallel & 5 \\
\hline Total Capacity & $420 \mathrm{~V}, 539.22 \mathrm{Ah}$ \\
\hline \multicolumn{2}{|c|}{ Grid Characteristic } \\
\hline No of phases & Three \\
\hline Voltage rating & 415VL-L,240V/ $\varphi$ \\
\hline Frequency & $50 \mathrm{~Hz}$ \\
\hline
\end{tabular}

\section{OPERATIONAL CONSIDERATION OF GRID CONNECTED PV SYSTEM}

The power generated from this photovoltaic system design is very much in excess. For the neighbourhood to benefit and to recoup part of the investment, the excess need to be injected into the grid in exchange for cash. However, it must be stated that as at time of this publication, there is no single grid connected PV power system in Nigeria.

The power parameters coming from the inverter must comply with the grid requirement since the system is grid-connected. Before connecting to the grid, there are technical requirement to be complied with. This is necessary for good power quality, safety of the users and the power system. In Nigeria situation, the operating frequency is $50 \mathrm{~Hz}$ and at this distribution level, each phase voltage is $240 \mathrm{~V}$ while line-line voltage is $415 \mathrm{~V}$. The ripple and harmonic created in power electronic is filtered to prevent power quality problems.

The conditions are:

> Compatibility of Phase Sequence: The phase sequence of the PV power system should be matched with that of the grid. In a three phase power systems, the phases are $120^{\circ}$ apart

$>$ Frequency Matching. The grid frequency in Nigeria and UK is $50 \mathrm{~Hz}$ and most of electrical appliances in these countries operate on this frequency. So the PV Inverter system has to be stable on $50 \mathrm{~Hz}$ with little tolerance before it can be synchronised into grid
$>$ Voltage Compatibility. The output voltage of the PV inverter to be connected to the grid must be of the same amplitude

Synchronisation of the inverter with the grid is achieved by the use of a Phase Locked Loop circuit. A phase-locked loop (PLL) is an electronic circuit with a current or voltage-driven oscillator that continuously adjusts the inverter signal to match the phase and frequency of the utility system. The phase locked loop generates an error signal when the output waveform of the inverter is not in phase with that of the mains supply. This error signal is used by the inverter to synchronise (locked on) its output waveform with that of the mains supply.

\section{SIMULATION RESULT AND DISCUSSION}

Using the archived solar resource and weather data of the defined location, as well as inputted design, the software run and gave expected amount of electric energy production in each month, the number of modules the design can accommodate and the performance ratio of the systems. The simulation gives hourly energy yield of the system for a whole year. The system starts to generate as early as 8:00hour even by 7:00 till 17:00hours sometimes till 18:00 hour depending on the month or season of the year. The daily production reaches peak between 11:00 to 14:00 hour; again the peak hour period changes in different day even within the same month depending on the season. Table 4 shows the total energy yield in every month. The highest production occurs in March, November and December. The least production occurs in July and August. The total yearly production is $212,586 \mathrm{kWh}$ from the installed PV system capacity of $148.5 \mathrm{kWp}$.

The tilt angle of the array is $15^{0}$ to the horizontal instead of $7^{0}$, the latitude angle of the location. Although for fixed installation, the location latitude is always the modules' tilt angle for maximum solar energy capture; it is however, not technically advisable in this location because the module should be mounted at least at tilt angle of $15^{\circ}$. This will allow easy flows of rain water, thereby washing off dust or dirt on the module surface. The difference in yield at $7^{0}$ and $15^{0}$ is $1990 \mathrm{kWh} /$ year. This is significant, an average of $5.5 \mathrm{kWh}$ per day. But it has to be traded off, so as not to have higher losses due to dust and dirt accumulation on the module surface.

Also, the energy yield was investigated at different angles of tilt. Table 5 shows the energy yield at different tilt angles. It is also interesting to note that while $0^{0}$ is not tilt angle of maximum possible energy production for fixed installation the energy generation at this tilt angle is higher in May, June, July and August than at $7^{0}$, the tilt angle for maximum generation

Similarly at $15^{0}$ tilt angle, the electrical energy production is higher in October, November, December 
and February than at $7^{\circ}$. At $30^{\circ}$, the energy production is highest in January, November and December. The energy yield at $45^{\circ}$ is lower to all the previous angles except in January, November and December where it is higher than production at $0^{0}$. Production at $60^{\circ}$ is the least and therefore should never be tilted at this angle. This confirms that PV system with solar energy tracking can yield much better than fixed installation [33]

\section{RECOMMENDATION}

\section{Leading by Example}

Nigeria Government at the three-tier (federal, state and local) level as well as various government parastatals should start massive deployment of photovoltaic systems by powering state houses, local government secretariat and various government agencies with photovoltaic system since these building are occupied mostly during the day when solar resources are normally available.

\section{Government Policy and Incentive}

Policies and government incentives aim at encouraging massive solar photovoltaic deployment need to be formulated and implemented. This will motive citizen to install PV systems in their home, particularly the homeowners if incentive like feed-in tariff, soft loan for PV system are offered. Much public awareness need to be created and improve understanding on the merits of PV generator over petrol-generator which is too common in the country.

\section{Training and Accreditation of PV Installer}

Adequate training should be given to technicians with specified minimum qualification and those found to be competent technician should be given licence to install PV systems. No untrained person be allowed to install PV system. This is necessary not only for standard and safety of the PV system but also for the systems' long term performance. This is one of the many areas where university, polytechnic, electrical energy companies and renewable energy developers can offers service to the society.

\section{Standard and Quality Monitoring.}

Since we are not yet manufacturing solar module and PV systems accessories, a standard and quality monitoring should be in place. This is because, instead of Nigeria business men and project executor to go for internationally acceptable standard product, they preferred to arrange for and import product with low quality [34].This will definitely reduce performance and durability of such products. Appropriate measure should be put in place to checkmate proliferation of substandard PV products. Solar PV products should have appropriate warranty.

\section{Table 4: Monthly energy production of the PV}

\begin{tabular}{llll}
\hline Months & $\begin{array}{l}\text { Irradiance onto } \\
\text { Horizontal plane } \\
\left(\mathrm{kWh} / \mathrm{m}^{2}\right)\end{array}$ & $\begin{array}{l}\text { Energy } \\
\text { Yield } \\
(\mathrm{kWh})\end{array}$ & $\begin{array}{l}\text { Daily } \\
\text { Average } \\
(\mathrm{kWh})\end{array}$ \\
\hline January & 141.20 & 19,398 & 625.74 \\
February & 138.29 & 18,299 & 653.54 \\
March & 155.34 & 20,053 & 646.87 \\
April & 149.01 & 18,584 & 619.47 \\
May & 153.20 & 18,294 & 590.13 \\
June & 129.60 & 15,539 & 517.97 \\
July & 116.02 & 13,802 & 445.23 \\
August & 114.58 & 14,435 & 465.65 \\
September & 120.96 & 15,521 & 517.37 \\
October & 142.79 & 18,874 & 608.84 \\
November & 147.40 & 20,258 & 675.27 \\
December & 140.51 & 19,529 & 629.97 \\
TOTAL & 1648.90 & 212,586 & 582.43 \\
\hline
\end{tabular}

Table 5: Monthly energy production at different tilt angles

\begin{tabular}{lcccccc}
\hline Months & $\begin{array}{c}\text { Energy Yield } \\
\text { at } 0^{0}(\mathrm{kWh})\end{array}$ & $\begin{array}{c}\text { Energy Yield } \\
\text { At } 7^{0}(\mathrm{kWh})\end{array}$ & $\begin{array}{c}\text { Energy Yield } \\
\text { at } 15^{\circ}(\mathrm{kWh})\end{array}$ & $\begin{array}{c}\text { Energy Yield } \\
\text { at } 30^{\circ}(\mathrm{kWh})\end{array}$ & $\begin{array}{c}\text { Energy Yield } \\
\text { at } 45^{0}(\mathrm{kWh})\end{array}$ & $\begin{array}{c}\text { Energy Yield } \\
\text { at } 60^{\circ}(\mathrm{kWh})\end{array}$ \\
\hline January & 18,225 & 18,939 & 19,398 & 19571 & 18895 & 17447 \\
February & 17,715 & 18,117 & 18,299 & 18118 & 17109 & 15325 \\
March & 19,929 & 20,151 & 20,053 & 19224 & 17555 & 15121 \\
April & 19,161 & 19,047 & 18,584 & 17001 & 14751 & 11903 \\
May & 19,683 & 19,231 & 18,294 & 15982 & 13095 & 9697.7 \\
June & 16,798 & 16,386 & 15,539 & 13636 & 11155 & 8397.5 \\
July & 14,965 & 14,588 & 13,802 & 12023 & 9788.7 & 7255 \\
August & 14,939 & 14,815 & 14,435 & 13221 & 11620 & 9598.2 \\
September & 15,667 & 15,724 & 15,521 & 14617 & 13082 & 11021 \\
October & 18,457 & 18,803 & 18,874 & 18432 & 17175 & 15176 \\
November & 19,056 & 19,785 & 20,258 & 20394 & 19596 & 17980 \\
December & 18,149 & 18,991 & 19,529 & 19822 & 19412 & 18105 \\
TOTAL & 212,745 & 214,576 & 212,586 & 202,041 & 183,234 & 157,026 \\
\hline
\end{tabular}




\section{CONCLUSION}

From the PV design analysis presented, the system energy yield is much more than satisfactory. The least daily energy production is $445.23 \mathrm{KWh}$ which occurs in July and highest daily energy yield is $675.27 \mathrm{kWh}$ in November as against maximum $131.51 \mathrm{kWh}$ daily consumption. The power generated far exceed demand, hence the need to export to the grid. The design implementation is a worthwhile project for the Local Government. The PV system is viable and reliable for power generation for offices that are mostly occupy during the day. In addition the design is technically sound and hopefully could produce the same results when implemented. It can help the local government generate electric energy for its use and as well export excess to the grid while at the same encouraging the community to generate electricity through photovoltaic system. This will in no small measure contribute to PV renewable energy deployment in the country.

\section{REFERENCES}

[1] Population of Nigeria 2016 and Historical Available at http://www.worldometers.info/worldpopulation/Nigeria-population/ Accessed on 25 Aug 2016

[2] Chris Newsom, Renewable Energy Potential in Nigeria: Low-carbon approaches to tackling Nigeria's energy poverty. International Institute for Environment and Development (IIED), London, UK. Available http://pubs.iied.org/pdfs/G03512.pdf. 2012.

[3] Lanre Okanlawon, The Potential of Nigeria's Residential Solar Rooftop Systems. Feb 25, 2015 Available at: renewableenergyworld.com/ugc/blogs/2015/02/t he-potential-of-nigerias-residential-solar-rooftopsystems.html Accessed on: 10 June 2016

[4] J O.Oji, N. Idusuyi, T. O. Aliu, M. O. Petinrin, O. A. Odejobi, and A. R. Adetunji, Utilization of Solar Energy for Power Generation in Nigeria. International Journal of Energy Engineering, , 2(2): 54-59 2012.

[5] Vytautas Adomavičius and Mantas Kaminickas, Analysis of PV Power Future Development Possibilities. Energetika. 2014. T. 60. Nr. 4. P. 233248

[6] G. Masson, M. Latour, M. Rekinger, et al. Global Market Outlook for Photovoltaics 2013-2017. Brussels, Belgium: European Photovoltaic Industry Association (EPIA), 2013.

[7] Daniel 0. Johnson. A Comparative Analysis of Photovoltaic Technologies for Renewable Energy Generation. Proceedings of 12th Photovoltaic
Science, Application and Technology PVSAT-12 Conference, University of Liverpool, Liverpool, 68th April 2016

[8] O. S. Ohunakina, M. S. Adaramola, O. M. Oyewola and R. O. Fagbenle, Solar energy applications and development in Nigeria: Drivers and barriers. Renewable and Sustainable Energy Reviews, Volume 32, April, Pages 294-3012014.

[9] M. Shaabana and J.O. Petinrin, Renewable energy potentials in Nigeria: Meeting rural energy needs. Renewable and Sustainable Energy Reviews, Volume 29, January Pages 72-84 2014.

[11] Y. N. Udoakah, and M. A Umoren, Analysis of Solar Potential and Energy Production of Photovoltaic Modules at Optimum Tilt Angles in Nigeria. Nigerian Journal of Solar Energy, Vol. 26, 2015

[12] [12] D. O. Akinyele and R. K. Rayudu, Distributed Photovoltaic Power Generation for Energy-Poor Households: The Nigerian Perspective. IEEE Power and Energy Conference, IEEE PES Asia-Pacific, 8-11 December,

2013 DOI: $10.1109 /$ APPEEC.2013.6837165

[13] Abdul Ghafoorn and Anjum Munir, Design and Economics Analysis of an off-grid PV System for Household Electrification Renewable and Sustainable Energy Reviews 42 496-502 2015.

[14] Muyiwa S. Adaramola, Viability of grid-connected Solar PV energy system in Jos, Nigeria. International Journal of Electrical Power and Energy Systems 61 64-69. 2014.

[15] A. H. Mondal and S. Islam, Potential and viability of grid-connected solar PV system in Bangladesh. Renewable Energy 36 (2011) 1869-1874.

[16 ] A. Shukla, K. Sudhakar and P. Baredar, Simulation and Performance Analysisof110kWp Gridconnected Photovoltaic System for Residential Building in India: A Comparative Analysis of Various PV Technology. Energy Reports 2, .. 82-88. 2016.

[17] R. Carbone, Grid-Connected Photovoltaic Systems with Energy Storage International Conference on Clean electrical Power, June Capri, Italy. 2009.

[18] S.M. Pietruszko and M. Gradzki, Performance of a grid connected small PV system in Poland. Applied Energy 74 177-184, 2003.

[19] Martin Mitscher and Ricardo Ruther, Economic performance and policies for grid-connected residential solar Photovoltaic systems in Brazil. Energy Policy 49 688-694 2012.

[20] European Photovoltaic Industry Association (EPIA).Global Market Outlook for Photovoltaics until 2015, Brussels, 2011.

[21] M. Braun, T. Stetz, R. Bründlinger, C. Mayr, K. Ogimoto, H. Hatta, et al. Is the distribution grid 
ready to accept large- scale photovoltaic deployment? State of the art, progress, and future prospects Progress in Photovoltaic: Res Appl, 20 pp. 681-697. 2012.

[22] John Ware, Solar Photovoltaic Power Supply System, IET Wiring Matters, 2007,

[23] Guide to the Installation of Photovoltaic Systems. Microgeneration Certification Scheme, London, 2012.

[24] Guda, H. A and Aliyu U. O., Design of a Stand-Alone Photovoltaic Systemfor a Residence in Bauchi. International Journal of Engineering and Technology Volume 5 No. 1, January, 2015

[25] Bo Yang, Wuhua Li, Yi Zhao, and Xiangning He, Design and Analysis of a Grid-Connected Photovoltaic Power System. IEEE Transactions on Power Electronics, Vol. 25, No 4, April 2010

[26] Manasseh Obin and Robert Bass, Trends and Challenges of Grid-Connected Photovoltaic Systems-A Review. Renewable and Sustainable Energy Reviews 58, 2016 pg 1082-1094.

[27] Leonics, How to Design Solar PV System, Available at: http://www.leonics.com/support/article2_12j/ articles2_12j_en.php Assessed on 15th August 2016.

[28] COOPER Bussmann, Photovoltaic System Protection Application Guide. Burton-on-the-Wolds, 2012 Available at: http://www1.cooperbussmann.com/pdf /1b416a65-f5ac-4730-ab77-9e2faa147945.pdf Accessed on: 23rd Aug. 2016

[30] Bussmann Series, Solar Circuit Protection Application Guide: Complete and Reliable Solar Circuit Protection. Eaton, Moon Township, USA, 2014. Available at: http://www.cooperindustries.com/content/dam/p ublic/bussmann/Electrical/Resources/technicalliterature/bus-ele-an-10191-pv-app-guide.pdf Accessed on 30 August 2016

[31] ABB Limited, Solar energy: Protecting and isolating PV systems, Coventry, 2014.

[32] C. Greacen, R. Engel and T. Quetchenbach, A. Guidebook on Grid Interconnection and Islanded Operation of Mini-Grid Power Systems Up to 200kW Lawrence Berkeley National Laboratory, April 2013 Available at: http://www.cleanenergyministerial.org/Portals/2/ pdfs/A Guidebook for MinigridsSERC LBNL March 2013.pdf Assessed on 19th August 2016.

[33] R. Corio, M. Reed and L. Fraas Tracking the Sun for More Kilowatt Hour and Lower-Cost Solar Electricity IN: Solar Cell and their Application 2nd ed. edited by L Frass and L. Partainpg, New Jersey: John Wiley\& Son 2010.

[34] A. S. Sambo, I. H. Zarma, P. E. Ugwuoke, I. J. Dioha, Y. M. Ganda, Implementation of Standard Solar PV Projects in Nigeria. Journal of Energy Technologies and Policy Vol.4, No.9, 2014. 